\title{
Hyperoxaluria after resection of ileum in childhood
}

\author{
H. B. VALMAN, V. G. OBERHOLZER, and T. PALMER \\ From Queen Elizabeth Hospital for Children, Hackney Road, London
}

\begin{abstract}
Valman, H. B., Oberholzer, V. G., and Palmer, T. (1974). Archives of Disease in Childhood, 49, 171. Hyperoxaluria after resection of ileum in childhood. Hyperoxaluria was found in 4 of 10 children who had had resection of the ileum. There was no relation between hyperoxaluria and the length of the resection or period since the resection. Previous studies have shown reduced ratios of taurine-conjugated to glycine-conjugated bile salts in the small intestine after ileal resection and we have found low levels of taurine in the urine of these patients. There was no correlation between the urinary taurine level and hyperoxaluria. In view of the variable excretion of oxalate in some patients, the high incidence of renal stones in adults with secondary hyperoxaluria, and the possibility of dietary treatment, regular estimations of urinary oxalate should be performed in children who have had resection of the ileum.
\end{abstract}

Hyperoxaluria and renal stones occurring after small intestinal resection were first described by Smith et al. (1970). Three further reports have been published (Dowling, Rose, and Sutor, 1971; Admirand, Earnest, and Williams, 1971; Chadwick, Modha, and Dowling, 1973). The majority of the patients in these studies had regional enteritis and all were adults. We have investigated the urinary excretion of oxalate in 10 children who have had resections of ileum and have no persisting disease to show the incidence of hyperoxaluria and to determine whether it is related to the length or site of the resection and the period since the resection.

Oral taurine therapy has been reported to be of benefit in at least some patients with secondary hyperoxaluria (Admirand et al., 1971; Dowling et al., 1971) and it has been suggested that there is a deficiency of taurine (Admirand et al., 1971). We have measured the taurine levels in plasma and urine specimens from some of our patients.

\section{Patients and methods}

The present ages of the patients and the time since their resections vary between 2 and 15 years (see Table). The percentage of small gut resected and the length of terminal ileum left is shown in the Table.

Urine oxalate was determined by the method of Giterson, Slooff, and Schouten (1970). Hockaday et al. (1965) and Gibbs and Watts (1969) showed that the normal range of oxalate excretion in children was similar

Received 7 September 1973. to the normal range in adults provided that the results in children were adjusted for surface area.

Amino acid levels in urine and in plasma after deproteinization with picric acid were determined on a Technicon amino acid analyser (21 hour) as previously described (Palmer, 1968). The standard Technicon buffer system (without methanol) was used, and the column was maintained at $35{ }^{\circ} \mathrm{C}$ for $4 \frac{1}{2}$ hours before raising the temperature to $60^{\circ} \mathrm{C}$.

\section{Results}

Of the 10 patients, 4 had definitely raised 24-hour urinary oxalate excretions (see Table). None of the patients has had urinary symptoms and none has radio-opaque renal stones at present. In a special study of one patient, random specimens of urine collected over a year showed the following levels: $0.15,0.011,0.002,0.006,0 \mathrm{mg}$ oxalate $/ \mathrm{mg}$ creatinine (normal range $0-0.029 \mathrm{mg} / \mathrm{mg}$ creatinine).

Every urine specimen investigated had a level of taurine near or below the lower limit of the normal range. All other urine amino acid levels were within normal limits.

One of the patients had a raised plasma cystathionine level of $0.04 \mathrm{mg} / 100 \mathrm{ml}$. Apart from this, every amino acid level in every plasma specimen investigated was within normal limits.

\section{Discussion}

In their first study, Dowling et al. (1971) found that 8 out of 11 adults with ileal dysfunction had 


\begin{tabular}{|c|c|c|c|c|c|}
\hline Cases & Present age (yr) & Age at resection (yr) & $\begin{array}{l}\text { Percentage of small } \\
\text { gut resected }\end{array}$ & $\begin{array}{l}\text { Terminal ileum left } \\
(\mathrm{cm})\end{array}$ & $\begin{array}{c}\text { Time since } r \\
(y r)\end{array}$ \\
\hline $\begin{array}{r}1 \\
2 \\
3 \\
4 \\
5 \\
6 \\
7 \\
8 \\
9 \\
10\end{array}$ & $\begin{array}{r}12 \\
7 \\
6 \\
15 \\
8 \\
6 \\
7 \\
7 \\
2 \\
14\end{array}$ & $\begin{array}{r}10 \\
3 \\
\mathrm{~N} \\
\mathrm{~N} \\
\mathrm{~N} \\
\mathrm{~N} \\
2 \\
5 \\
\mathrm{~N} \\
\mathrm{~N}\end{array}$ & $\begin{array}{l}35 \\
70 \\
50 \\
35^{\star} \\
70 \\
40 \\
35^{\star} \\
50^{\star} \\
70 \\
45^{\star}\end{array}$ & $\begin{array}{r}0 \\
7 \\
0 \\
30 \\
12 \\
10 \\
0 \\
2 \\
26 \\
0\end{array}$ & $\begin{array}{r}2 \\
4 \\
6 \\
15 \\
8 \\
6 \\
5 \\
2 \\
2 \\
14\end{array}$ \\
\hline
\end{tabular}

Normal

hyperoxaluria, and in a larger series (Chadwick et al., 1973) there were 10 out of 18 . 5 of the 18 patients with ileal resection but without nephrolithiasis described by Smith, Fromm, and Hofmann (1972) had hyperoxaluria, and the incidence in the present series is similar.

The age at resection, the percentage of gut resected, and the length of the remaining terminal ileum did not appear to be related to the oxalate excretion (see Table). This confirms the observations of Smith (1972), though there have been suggestions, without supporting details, that the oxalate excretion is related to the length of ileum resected (Stauffer and Humphreys, 1972; Chadwick et al., 1973). In 2 children the amount excreted was determined on more than one occasion and was found to be variable, confirming the observation in one patient described previously (Dowling et al., 1971). Similarly, random urine specimens from one child gave results both within and outside the normal range. Hence, it would be unwise to assume that children found to have a normal oxalate excretion on one occasion would never have hyperoxaluria. Dowling et al. (1971) found that 3 of 8 patients with hyperoxaluria had renal stones, and Smith et al. (1972) found stones in 7 out of 12 patients. This suggests that as the children in the present series have a long life expectancy there is a high risk of oxalate renal stones.

Ileal resection leads to a reduced reabsorption of bile salts and subsequently to increased demand for synthesis and conjugation of bile acids in the liver. A greatly increased synthesis of bile acid glycine has been shown in some patients (Smith et al., 1972).
The ratio of glycine to taurine-conjugated bile salts in the small intestinal lumen is increased tenfold (McLeod and Wiggins, 1968), which may be due to a limited ability of the liver to increase the synthesis of taurine or to the inability of the jejunum to reabsorb taurine-conjugated bile salts (Hislop, Hofmann, and Schoenfield, 1967). It has been suggested that the hyperoxaluria in these patients is related to the increased ratio of glycine-conjugated bile salts (Smith et al., 1970; Admirand et al., 1971; Smith et al., 1972) since glycine is a major precursor of oxalate (Williams and Smith, 1972). Recent studies have shown that it is more likely to result from an increased absorption of oxalate by the intestine (Chadwick et al., 1973). This provides an explanation for the variability of the urinary oxalate excretion, since it would depend on the diet.

Cholestyramine has been found to reduce the urinary oxalate excretion to normal (Smith et al., 1972), but in one patient the treatment had to be stopped as there was persistent diarrhoea. This drug may reduce the intestinal absorption of oxalate (Chadwick et al., 1973). Oral calcium might also reduce oxalate absorption by forming insoluble calcium oxalate in the gut. However, the most effective treatment appears to be a low oxalate diet (Chadwick et al., 1973), but it has been suggested that this therapy should be restricted to patients with recurrent renal stones.

Oral taurine has been found to abolish the hyperoxaluria in some patients (Dowling et al., 1971; Admirand et al., 1971), but has been ineffective in others (Smith et al., 1972; Chadwick et al., 1973). The low urinary taurine levels in our patients 
chemical results

\begin{tabular}{|c|c|c|c|}
\hline $\begin{array}{l}\text { 24-hour urinary oxalate } \\
\left(\mathrm{mg} / \mathrm{l} \cdot 73 \mathrm{~m}^{2} \text { surface area) }\right.\end{array}$ & $\begin{array}{l}\text { Urinary taurine excretion } \\
(\mathrm{mg} / \mathrm{g} \text { nitrogen })\end{array}$ & Plasma taurine $(\mathrm{mg} / 100 \mathrm{ml})$ & Reason for resection \\
\hline $\begin{array}{l}90 \cdot 3 \\
86 \cdot 5,67 \cdot 0 \\
79 \cdot 6 \\
0,52 \cdot 5 \\
42 \cdot 8 \\
38 \cdot 1 \\
39 \cdot 8 \\
24 \cdot 8 \\
0 \\
8 \cdot 6\end{array}$ & $\begin{array}{l}2 \cdot 1 \\
0 \cdot 89,<0 \cdot 45 \\
2 \cdot 9 \\
4 \cdot 1 \\
\\
2 \cdot 1 \\
1 \cdot 3 \\
1 \cdot 8,2 \cdot 9\end{array}$ & $\begin{array}{l}1 \cdot 25 \\
1 \cdot 3 \\
0 \cdot 65 \\
1 \cdot 15 \\
\\
\\
\\
1 \cdot 0,1 \cdot 0\end{array}$ & $\begin{array}{l}\text { Tuberculosis and stagnant loop syndrome } \\
\text { Volvulus and malrotation } \\
\text { Volvulus and atresia } \\
\text { Multiple atresia } \\
\text { Volvulus and malrotation } \\
\text { Septum in ileum } \\
\text { Long segment Hirschsprung's disease } \\
\text { Sickle cell crisis with infarction } \\
\text { Volvulus and malrotation } \\
\text { Atresia }\end{array}$ \\
\hline $\begin{array}{c}0-36 \mathrm{mg} / 24 \mathrm{hr} \\
\text { (range) }\end{array}$ & $\begin{array}{c}2 \cdot 2-22 \\
\text { (range) } \\
(3 \mathrm{yr}-16 \mathrm{yr})\end{array}$ & $\begin{array}{c}0.85 \pm 0.45 \\
(\text { mean } \pm S D) \\
(3 ! \text { mth-12 yr })\end{array}$ & \\
\hline
\end{tabular}

confirm that ileal resection may lead to taurine depletion but show that there is no correlation between taurine excretion and hyperoxaluria. Hyperoxaluria and low taurine excretion are two of the consequences of ileal resection but may not be directly related. Low urinary levels of taurine are found in subjects having low protein intakes (Evered et al., 1969), but all our patients were having higher than normal protein intakes.

It may be surprising that plasma levels of taurine were normal while urine levels were low. A similar situation is found in normal infants, for though taurine is virtually absent from the urine of children 2 weeks to 1 year of age, plasma levels are not reduced during this period and there is a marked reduction in renal clearance (Palmer, 1973). The explanation is not known, but the possibility of a protein-bound taurine fraction in the plasma is being investigated.

We thank Dr. R. W. E. Watts for constructive criticism; and Mr. V. A. J. Swain and Mr. J. A. S. Dickson for allowing us to study these patients.

REFERENCES

Admirand, W. H., Earnest, D. L., and Williams, H. E. (1971). Hyperoxaluria and bowel disease. Transactions of the Association of American Physicians, 84, 307.

Chadwick, V. S., Modha, K., and Dowling, R. H. (1973). Mechanism for hyperoxaluria in patients with ileal dysfunction. New England fournal of Medicine, 289, 172.

Dowling, R. H., Rose, G. A., and Sutor, D. J. (1971). Hyperoxaluria and renal calculi in ileal disease. Lancet, $1,1103$.
Evered, D. F., Harvey, M. S., Luck, L. J., and Solari, M. E. (1969). The relationship between urinary taurine excretion and the intake of protein-rich foods. Life Sciences, 8, 601.

Gibbs, D. A., and Watts, R. W. E. (1969). The variation of urinary oxalate excretion with age. Fournal of Laboratory and Clinical Medicine, 73, 901.

Giterson, A. L., Slooff, P. A. M., and Schouten, H. (1970). Oxalate in urine. Clinica Chimica Acta, 29, 342.

Hislop, I. G., Hofmann, A. F., and Schoenfield, L. J. (1967). Determinants of the rate and site of bile acid absorption in man. Fournal of Clinical Investigation, 46, 1070.

Hockaday, T. D. R., Frederick, E. W., Clayton, J. E., and Smith, L. H. (1965). Studies on primary hyperoxaluria. fournal of Laboratory and Clinical Medicine, 65, 677.

McLeod, G. M., and Wiggins, H. S. (1968). Bile-salts in small intestinal contents after ileal resection and in other malabsorption syndromes. Lancet, 1, 873.

Palmer, T. (1968). 6th colloquium in amino acid analysis. Technicon Monograph, 3, 95. Technicon International Division, Geneva, Switzerland.

Palmer, T. (1973). Amino acid levels in blood cerebrospinal fluid and urine in normal and sick children. Ph.D. Thesis. London University.

Smith, L. H. (1972). Hyperoxaluria with intestinal disease. (Letter) New England fournal of Medicine, 287, 412.

Smith, L. H., Fromm, H., and Hofmann, A. F. (1972). Acquired hyperoxaluria nephrolithiasis and intestinal disease. New England fournal of Medicine, 286, 1371.

Smith, L. H., Hofmann, A. F., McCall, J. T., and Thomas, P. J. (1970). Secondary hyperoxaluria in patients with ileal resection and oxalate nephrolithiasis. (Abst.) Clinical Research, 18, 541.

Stauffer, J. Q., and Humphreys, M. H. (1972). Hyperoxaluria with intestinal disease. (Letter) New England fournal of Medicine, 287, 412 .

Williams, H. E., and Smith, L. H. (1972). Primary hyperoxaluria. In The Metabolic Basis of Inherited Disease, 3rd ed., p. 196. Ed. by J. B. Stanbury, J. B. Wyngaarden, and D. S. Frederickson. McGraw-Hill, New York.

Correspondence to Dr. H. B. Valman, Northwick Park Hospital and Clinical Research Centre, Harrow, Middlesex HA1 3UJ. 